Meta

Journal des tradlucteurs

Translators' Journal

\title{
Some Abbreviations for Energy Units in France
}

\section{Hugh Myers}

Volume 19, numéro 4, décembre 1974

URI : https://id.erudit.org/iderudit/003685ar

DOI : https://doi.org/10.7202/003685ar

Aller au sommaire du numéro

Éditeur(s)

Les Presses de l'Université de Montréal

ISSN

0026-0452 (imprimé)

1492-1421 (numérique)

Découvrir la revue

Citer cet article

Myers, H. (1974). Some Abbreviations for Energy Units in France. Meta, 19(4), 203-205. https://doi.org/10.7202/003685ar d'utilisation que vous pouvez consulter en ligne.

https://apropos.erudit.org/fr/usagers/politique-dutilisation/ 


\section{PROBLÈMES ET SOLUTIONS}

\section{SOME ABBREVIATIONS \\ FOR ENERGY UNITS IN FRANCE}

In January and February of 1974, France's well-known weekly railroad review, la Vie du rail (VDR), carried a series of five essays on Énergie et Transport in France and the rest of the world. My present remarks on these essays are offered in the belief that the $V D R$ series contained some abbreviations for energy units that will be of interest to French-to-English translators. Most of the units are big and therefore especially appropriate when we are considering energy consumption, needs and shortages on national or global scales. Since energy in this context is one of the main topics of the day, I expect reference to the energy units in many French writings, much more so than in the past, and I expect the abbreviations to be taken for granted and given without explanation.

I do not think that the abbreviations and acronyms to be discussed are familiar to most translators who are not specialized in technical work, but so that each reader may judge of that for himself, let us list them forthwith : Gec, Tec, $M$ de Tec or $M T e c, M t h, M W e, T W h$ and $E$.

\section{Gec and $\mathrm{Tec}$}

The kilowatt-hour (kwh) is the most usual energy unit in France ${ }^{1}$. However, general discussions of energy involve a great many fuels as well as hydraulic energy sources. Since the calorific value (pouvoir calorifique) of one fuel will not be that of another (different fuels having different heat potentials), the French have accepted coal as the standard fuel and talk of l'équivalent charbon (coal equivalent) of other heat energy sources. Since common units of weight are the gram and the metric ton, France has the Gec, or gramme d'équivalent charbon, and the Tec, or tonne d'équivalent charbon. A Gec is the heat energy equivalent of a gram of coal;

1. La Vie du rail, no 1425 , p. 46 . 
and a Tec, that of a ton of coal. Only $0,3 \mathrm{Tec}$, we are told, will produce 1000 kwh or 3413000 BTU $^{2}$.

I should mention that I have adopted the French usage of the VDR essays for the purposes of these notes. Of course there are other possibilities in French. For example, Harrap's New Standard French and English Dictionary lists TEC (each letter capitalized), and writes it out as tonne-équivalent-charbon, not tonne d'équivalent charbon. I might add that I have so far found gec only in VDR and in a speech I translated from French to English.

\section{$M$ de Tec or MTec and $M$ th}

The energy unit called $M$ de Tec or $M T e c$ is of course a million Tec. Some idea of its size may be derived from the fact that transportation in France consumed only $43 \mathrm{MTec}$ in the whole of $1972^{3}$.

The $M t h$ is another enormous unit meaning un million de thermies (a million thermal units). The French thermal unit equals a thousand kilogram calories, and is thus very much larger than our familiar BTU. Just one French thermal unit, to say nothing of a million, will raise the temperature of a metric ton of water from $15^{\circ}$ to $16^{\circ} \mathrm{C}$.

\section{$M W e, T W h$ and $E$}

These units express large quantities of energy in terms of electrical power. The smallest of the three giants is the $M W e$, which is a mégawatt électrique ${ }^{4}$. In writing out this expression, $V D R$ explains that $M W e$ are « millions de $\mathrm{kW}$ installés. » For «millions» we should probably read «milliers» in order to have only a million (méga) and not a billion watts.

Why does the French say $M W e$ instead of the familiar $M W$, which we know is a megawatt? The answer seems to lie in the word installee : an $M W e$ is not a million watts anywhere, at a power station for example, but a million watts actually installed and available for use (though not necessarily used).

Energy consumption on a national or world scale may also be measured in TWh - térawatt-heures, which are billions of kwh produced ${ }^{5}$. How big is the $T W h$ ? Well, the smaller European countries use a few dozen $T W h$ per year; larger countries may consume a few hundred of them, and the world consumption of electric power amounted to $5276 \mathrm{TWh}$ in $1971^{\circ}$.

Finally, there is the unbelievable $E$, so big that its usefulness in discussion is perhaps limited to surveys of world energy needs or consumption over periods of many years. An $E$ is a million $T W h$. VDR records that the word used $25 E$ between the birth of Christ and $1850 ; 12 E$ from 1850 to 1950 ; and may need from 300 to $1000 E$ between 1950 and $2050^{7}$.

\footnotetext{
2. La Vie du rail, $\mathrm{n}^{\circ} 1425$, p. 46.

3. Ibid., $\mathrm{n}^{\circ} 1429$, p. 54.

4. Ibid., $\mathrm{n}^{\circ} 1428$, p. 45 .

5. Ibid.

6. Ibid., $\mathrm{n}^{\circ} 1425$, p. 46 .
} 
That concludes our discussion for the moment, then. If I have insisted a great deal on abbreviations, it is because practical experience amply demonstrates, I believe, that there is nothing like an unfamiliar abbreviation to trip up translator and hinder work that is otherwise going quite well.

HUGH MYers 